This is the authors' version of a work that was submitted to / accepted for publication.

To cite this chapter: Hemming, P.J \& Hailwood, E. (2018) 'Religious Citizenship in Schools in England and Wales: Responses to Growing Diversity', in A. Peterson, G. Stahl \& H. Soong (eds.), The Palgrave Handbook of Citizenship and Education, Cham: Palgrave Macmillan. https://doi.org/10.1007/978-3-319-67905-1 44-1

\title{
Religious Citizenship in Schools in England and Wales: Responses to Growing Diversity
}

\author{
Peter J. Hemming (HemmingPJ@cardiff.ac.uk) \\ \& Elena Hailwood (HailwoodE@cardiff.ac.uk) \\ School of Social Sciences, Cardiff University, Cardiff, UK
}

\begin{abstract}
This chapter explores the concept of 'religious citizenship', in the context of statefunded schooling in England and Wales, and against a backdrop of growing religious pluralism. The chapter considers the role of various educational actors in determining the extent to which schools recognise and accommodate diversity of religion and belief. Aspects of education such as faith schools and pupil admissions, religious education and festivals, collective worship and prayer, and pupil values and interfaith relations are explored with reference to the existing body of research literature. In so doing, the chapter highlights an important dimension of the informal citizenship education that state-funded schools in England and Wales provide to pupils on the basis of their religion and belief.
\end{abstract}

Key Words: belief, citizenship, diversity, England, equity, faith, religion, rights, schools, Wales 


\section{Introduction}

In recent years, diversity of religion and belief has been increasingly recognised within social and public policy debates as distinct from 'race' and ethnicity and as worthy of attention in its own right. England and Wales ${ }^{1}$ have become progressively more diverse in religious terms since the turn of the $21^{\text {st }}$ century. Data from the Office for National Statistics (2015) shows that whilst the number of people identifying as Christian fell significantly in the period between the 2001 and 2011 Census, there were marked increases in respondents with no religion, and smaller but nevertheless notable increases in those from Muslim, Hindu, Sikh, Buddhist and other minority faith backgrounds (see Figure 1).

\begin{tabular}{|c|c|c|}
\hline & 2001 & 2011 \\
\hline Christian & $71.8 \%$ & $59.3 \%$ \\
\hline No Religion & $14.8 \%$ & $25.1 \%$ \\
\hline Muslim & $3.0 \%$ & $4.8 \%$ \\
\hline Hindu & $1.1 \%$ & $1.5 \%$ \\
\hline Sikh & $0.6 \%$ & $0.8 \%$ \\
\hline Jewish & $0.5 \%$ & $0.5 \%$ \\
\hline Buddhist & $0.3 \%$ & $0.4 \%$ \\
\hline Other Religions ${ }^{2}$ & $0.3 \%$ & $0.4 \%$ \\
\hline Not Stated & $7.7 \%$ & $7.2 \%$ \\
\hline
\end{tabular}

Figure 1: Census Figures, Office for National Statistics

Bouma \& Ling (2009: 509) argue that: "the theme of the early twenty-first century appears to be religious diversity and its consequences for social order and public life". Religious pluralism may present a number of issues and challenges for societies to grapple with, such as how the state can adequately accommodate for diverse religious needs within public service provision. Machacek (2003) argues that the biggest challenges are likely to arise in fields such as education, where participation is (relatively) compulsory ${ }^{3}$ for all religious and non-religious groups. Many schools in England and Wales now find they are catering for a greater diversity of religion and belief amongst their pupils than was previously the case. As such, questions about 
how these groups should be provided for in schools have become more common (e.g. see Pring 2018, Wilson 2015). Many of the judgements made in these cases have the issue of competing rights and interests at their core and cannot be fully understood without reference to citizenship.

Contemporary conceptions of citizenship have moved beyond notions of fixed rights and responsibilities bestowed upon citizens by law (e.g. Marshall (1950 [1973]). Instead, scholars have pointed to the fluid and contested nature of citizenship, and the on-going power struggles for rights and inclusions that it entails (Ho 2006). Similarly, citizenship is increasingly understood as encompassing issues of identity, belonging and inequalities, and thus possessing a social/cultural dimension, as well as a political one (Painter \& Philo 1995). In this light, citizenship is viewed as a complex process rather than a fixed given, encompassing both politics and culture, and constituted through everyday practices and discourses (Staeheli et al. 2012).

The concept of citizenship has traditionally been associated with 'race' and ethnicity (e.g. Kymlicka 2007), but researchers have also identified a number of other strands of difference through which processes of citizenship play out, including, for example, gender and sexuality (e.g. Bell 1995, Chouinard 2004). In the case of religion, Hemming (2015) has drawn on the work of Joppke (2007) and his three dimensions of citizenship - status, rights and identity - to interrogate the relationship between religion and the everyday practices and discourses of citizenship. Hemming (2015:27) defines 'religious citizenship' as: "the role of religion in devising criteria for access to state or community membership, the political rights and responsibilities attributed to particular religious groups within that membership, and the religious aspects of collective social/cultural identity that influence belonging".

In the context of education, religious citizenship is therefore concerned with religious influences on access to schooling, the ways in which particular religious and nonreligious groups are recognised and accommodated within schools, and the implications for pupil/parent identity and belonging. Fundamentally at stake here is social justice and the extent to which educational arrangements privilege certain groups over others. Evaluating these arrangements requires consideration of what Kymlicka (2007) refers to as 'the politics of identity' and 'the politics of interest'. Are 
there inequities in the extent to which different religious and non-religious identities are recognised through the types of schooling offered and the contents of the curriculum? How far are the interests of different groups accommodated in education through provision for diverse religious and non-religious needs? What are the effects of such arrangements on feelings of identity and belonging to school, community and society for members of different groups?

In order to investigate these issues, the chapter focuses on state-funded education in England and Wales. This includes non-denominational schools and schools with a religious character, which make up 34\% of all state-maintained schools in England and $16 \%$ in Wales (Long \& Bolton 2017, Welsh Government 2018). Aspects of education such as faith schools and pupil admissions, religious education (RE) and festivals, collective worship and prayer, and pupil values and interfaith relations, are considered with reference to the different roles played by various educational actors. Collectively these aspects constitute an important dimension of the informal citizenship education that state-funded schools in England and Wales provide to pupils on the basis of their religion and belief.

\section{Access: Faith Schools and Pupil Admissions}

The importance of religion for access to education in England and Wales is apparent in the case of schools with a religious character. Faith schools, as they are otherwise known, are significant for religious citizenship because they attempt to recognise and accommodate religious groups within the schooling system and thus encourage a wider sense of cultural belonging (Power \& Taylor 2013). The existence of faith schools in Britain is rooted in the historical involvement of the Christian churches in the development of universal education and the 'dual system' of state-led and churchled schooling in the late $19^{\text {th }}$ century (Baumfield 2003). After 1944, schools previously funded by religious bodies entered into a formal partnership with the state, ensuring state-funded Anglican, Roman Catholic and a smaller number of Methodist and Jewish schools (Jackson 2001).

There are now a number of different types of state-maintained faith schools in England and Wales, including voluntary controlled, voluntary aided and foundation schools ${ }^{4}$. In 
England, the rolling out of academies and free schools ${ }^{5}$ has created the potential for more schools with a religious character. All of these types of faith schools maintain a distinctive religious ethos and character, but enjoy different funding arrangements with, and levels of autonomy from, the state. After 1999, applications to establish voluntary aided faith schools from minority religious groups began to be accepted, and there are now a small number of state-maintained Islamic, Sikh, Hindu, Greek Orthodox and Seventh Day Adventist schools (amongst others) in England (Long \& Bolton 2017).

The above arrangements have implications for the level of access that different groups are granted to faith-based education. Firstly, the religious profile of schools does not match that of the population, as represented in Figure 1. In England, $99 \%$ of all statemaintained schools with a religious character are Christian-based and in Wales this figure is $100 \%$ (Long \& Bolton 2017, Welsh Government 2018). However, the Census figures for 2011 highlight that only $87 \%$ of those with a religion describe themselves as Christian with $13 \%$ identifying with a non-Christian faith (Office for National Statistics 2015). As such, schools with a minority religious character are significantly under-represented. Furthermore, $25 \%$ of the population have no religion, but there is no dedicated category of schools to cater for this group. Non-denominational schools are not technically secular (see section on collective worship) and typically cater for pupils from a range of backgrounds.

Secondly, levels of access to faith-based schools are particularly dependent on geography. As previously stated, $34 \%$ of all state-maintained schools in England possess a religious character but this figure is only $16 \%$ in Wales (Long \& Bolton 2017 , Welsh Government 2018). Church schools are distributed in certain ways due to historical factors, such as the large numbers of Anglican schools in rural villages, reflecting the church's traditional mission to provide education for the whole parish (Louden, 2012) or the concentration of Roman Catholic schools in North West England, due to the influx of Irish migrants to the region in past times (Flint 2007). The small numbers of state-maintained schools with a minority religious character, such as Islam, are located in urban, metropolitan areas and hence only accessible to families living nearby. Such arrangements reflect an unequal landscape of schooling, where certain groups have more access to faith-based education than others. 
Pupil admissions procedures can also play a role in access to faith-based education. Non-denominational schools cannot select pupils on the basis of faith but some schools with a religious character are permitted to do so. According to Allen \& West (2009, 2011), on aggregative, faith schools contribute to higher levels of ethnic and religious segregation in the education system and disproportionately cater for more affluent families. However, the picture is more complex than these patterns suggest. The majority of local authorities prevent their voluntary controlled faith schools from including religion on their admissions criteria and some faith-based academies are obliged to take a quota of pupils from other religious backgrounds (Fair Admissions Campaign 2013). In the case of other types of faith school, under-subscription may mean that admissions criteria do not come into operation, or schools may choose not to select by faith in order to cater for a wider cross-section of the community (e.g. Hemming 2018a). School admissions policies can, therefore, reinforce the existing inequities that different groups experience in access to education but there are also instances where they can mitigate such inequities.

It is also important to note that parents are not passive recipients of these processes. Research has shown that some middle-class Christian parents are adept at utilising strategies to gain admission to high performing church schools, through what has been referred to as the 'cashing in' of their faith-based resources (Butler \& Hamnett 2012). This may involve reaffirming a latent religious affiliation or recommencing church attendance at convenient moments, in order to obtain school admissions references from church leaders. However, there is also evidence of other groups negotiating the school system to their benefit, despite starting from a less privileged position in terms of access to faith-specific schooling provision. Muslim parents often favour church schools over non-denominational schools, where places are available, for the value they place on religion (Scourfield et al. 2013). Similarly, there is a range of reasons why non-religious families might choose to send their children to a school with a religious character where the option exists, including to take advantage of local or high quality provision (Hemming \& Roberts 2018).

The examples above further emphasise the contested nature of religious citizenship in the context of access to schooling. Although the education systems in England and 
Wales tend to privilege Christian groups, through access to disproportionately high numbers of church schools with a wider geographical distribution than other faith schools, the situation is continuously manipulated and contested by a range of actors. Faith schools themselves may reinforce or mitigate these inequities in access through exclusive or inclusive use of their religious-based admissions criteria. Parents from different religious and non-religious groups may also negotiate admissions requirements for their own ends, in order to try and gain access to more desirable schools. Religious citizenship in education can therefore be understood as a fluid and dynamic process involving a range of actors, rather than a fixed and static contract between citizen and state.

\section{Recognition: Religious Education and Festivals}

$\mathrm{RE}$ is an important vehicle through which schools can recognise diversity of religion and belief. In its current form, RE has been part of the curriculum in England and Wales since 1988, although syllabus content is set at the local, rather than national level. The subject has gradually evolved since 1944 from an approach based on evangelistic Christian instruction to education about world religions (Conroy et al. 2013, Copley 1997). RE in non-denominational schools is expected to reflect the

predominantly Christian nature of the religious traditions in Britain but also include the beliefs and practices of other principal religions represented nationally (National Association of Teachers of Religious Education 2017). Faith schools may teach RE in line with the beliefs of their religious denomination. However, voluntary controlled and foundation schools with a religious character usually follow the locally agreed syllabus. All parents have the right to withdraw their children from RE lessons, although this is rarely enacted in practice (Richardson et al. 2013).

The above arrangements have implications for the kind of RE experience received by pupils from different backgrounds. RE is widely viewed as important for citizenship, with the potential to develop interfaith understanding, promote common values and tackle religious discrimination (Baumann 1996, Madge et al. 2014). Several research studies suggest that pupils value $\mathrm{RE}$ as an opportunity to hear about different religions and worldviews from an objective viewpoint and may feel more inspired to learn about their own faith or beliefs as a result (Francis \& Robbins 2011, Jackson 2012, McKenna 
et al. 2009). However, pupils often ask for a more diverse range of traditions to be taught in RE lessons, in schools both with and without a religious character (Jackson 2004, Revell 2007).

The opportunity to study a broad range of religious traditions is usually reflected in locally agreed RE syllabuses in England and Wales but some researchers have expressed concern about the tokenistic coverage of non-Christian faiths (Nesbitt 2004). Many teachers lack confidence in delivering RE, often feeling they do not have adequate knowledge of different faiths (Revell 2007). Moreover, pupils from minority groups sometimes report that teachers do not accurately represent their religion in the classroom (Ipgrave 1999, Moulin 2011). The inclusion of non-religious worldviews in $\mathrm{RE}$ has become increasingly common, but is not yet as widespread as other religious traditions (Watson 2010). Pupils from different religious and non-religious groups therefore experience differing levels of coverage of their particular religious tradition or worldview in RE lessons. This has implications for citizenship, in terms of whether or not particular groups feel recognised and accepted within the school and wider community, as well as the extent to which pupils are adequately prepared for life in a diverse, multi-faith society.

Despite the above issues, parents and pupils can nevertheless become involved in contesting RE arrangements. The interests of non-religious groups were recently given a boost by a legal judgement concerning the content of a new GCSE exam syllabus for 14-16 year-olds. The ruling from the High Court stated that RE provision should include teaching about non-religious worldviews, such as humanism (R (Fox) v. Secretary of State for Education [2015]). Similarly, pupils from minority faith groups can also demonstrate resistance to RE teaching. Wilson (2015) conducted research in a Church of England primary school with a diverse pupil intake. He found that although learning about Christianity in RE was generally acceptable to Muslim pupils, in some circumstances, pupils adopted forms of resistant behaviour when they were worried about contravening their own faith, including fidgeting, not listening, and saying 'stafallah' (meaning 'Allah forgive me').

The celebration of religious festivals could also be understood as a type of RE. Christmas, Easter and Harvest Festival are generally marked with activities and 
celebrations in schools in England and Wales (Nesbitt 2004). The ability of minority pupils to participate in these Christian celebrations often depends on whether they are perceived as religious or cultural, such as if they are held in a church or school hall (Wilson 2015). Many schools also choose to mark minority religious festivals such as Eid, Diwali, Hanukkah and Vaisakhi (Keddie 2014, Nesbitt 2004). It is widely viewed as appropriate to recognise non-Christian festivals in an educational sense, during assemblies or classroom discussions (e.g. Catholic Education Service 2008). Some schools go further and hold school-wide celebrations by emphasising the cultural aspects of festivals, such as telling stories and sharing food, which can be popular with minority religious families. However, this approach can also result in a backlash from some Christian parents, particularly in church schools, who may view it as inappropriate (Hemming 2015).

In both the teaching of RE and the marking of religious festivals in schools, Christianity enjoys a certain amount of privilege, even if this is sometimes understood in a cultural rather than a religious sense. Schools often find themselves mediating between the desires of minority groups for more recognition of non-Christian beliefs and festivals, and the concerns of other parents that Christianity should maintain its primacy in the curriculum and for school celebrations. This typically involves attempting to strike an appropriate balance between the various sets of interests represented amongst school stakeholders. At the root of these issues is the struggle for proper recognition of different religious and non-religious groups, a key component of religious citizenship. The active role that schools, parents and pupils play in this process, further underlines the fluid and contested nature of religious citizenship in the context of education.

\section{Accommodation: Collective Worship and Prayer}

All schools in England and Wales are required to 'promote the spiritual, moral, social and cultural development of pupils' (Estyn 2017, Ofsted 2017). However, accommodating for the spiritual and cultural needs of minority groups sometimes requires changes to existing provision in schools. One example of this is the daily act of collective worship, which all schools are expected to provide. This should be of a 'wholly or mainly Christian character', unless the school has applied for a special exemption (Copley 2000). More commonly know as 'assemblies', such events involve 
whole-school gatherings of pupils and teaching staff and can be important for developing a shared identity within a school community (Hemming 2015). Research indicates that both pupils and teachers largely support and enjoy the collective, celebratory and moral aspects of assemblies, such as the presentation of awards for good work or the sharing of stories that promote desired behaviours (Gill 2000a). However, teachers in schools with multi-faith pupil intakes often view the religious components of assemblies as more contentious (Gill 2000b).

The expectation that assemblies will include Christian worship presents a number of difficulties for the accommodation of non-Christian pupils, especially as parents rarely enact the right to withdraw their children (Richardson et al. 2013). Consequently, many non-denominational schools no longer comply with the law, although Christian-based collective worship is still commonly practiced in church schools (Smith \& Smith 2013). The inclusion of stories and other material from different religious and non-religious traditions are popular ways of approaching assemblies in diverse contexts (Baumann 1996, Gill 2000b). Non-denominational schools tend to emphasise common values and virtues rather than explicitly Christian messages (Mogra 2017, Smith \& Smith 2013). It is possible, therefore, for schools to balance the requirements for collective worship set by the state, which predominantly favour Christianity, with the spiritual and cultural needs of pupils from other religious and non-religious groups.

In contexts where Christian worship does feature in assembly proceedings, for example in church schools, problems can arise (Smith 2005). Parents from nonChristian backgrounds sometimes express concerns about perceived indoctrination (Weller et al. 2015) and pupils may find Christian worship alienating or difficult to engage with (Kay \& Francis 2001, Scourfield et al. 2013). Such instances may lead pupils to adopt creative responses, such as changing the words of Christian prayers in their head to ensure they are consistent with their own faith (Hemming 2015). Whilst schools sometimes make provisions for minority religious pupils, such as allowing them to sit quietly during Christian prayers, non-religious pupils do not always receive the same recognition, which can be uncomfortable if they find prayer meaningless or insincere (Fancourt 2017, Hemming 2018b). Prayers that express common values, avoid reference to a specific God, and/or provide opportunities for non-religious reflection are likely to be more accessible for pupils from diverse backgrounds (Wilson 
2015). However, schools will need to balance the interests of different groups, as such approaches may lead to concerns from Christian parents about the perceived dilution of Christian worship (Hemming 2015, Nesbitt 2004).

There are a number of other spiritual and cultural needs that schools typically try to accommodate, including prayer, dietary and dress needs. Taking prayer as a case study, research indicates that whilst many schools aim to provide for these needs where possible, some could be more proactive in offering space and/or facilities such as prayer mats and washing areas (Conroy et al. 2013). For example, Hemming (2015) found that Muslim pupils in one multi-faith primary school did not always feel comfortable to pray during Ramadan because they did not have appropriate ways of storing their prayer mats to ensure they remained clean. Berkley \& Vij (2008) also note the importance of accommodating the spiritual needs of non-religious pupils, who may benefit from the provision of spaces dedicated to reflection or meditation.

Despite its importance, providing for diverse prayer needs is not always easy. In some circumstances, schools with a large proportion of pupils from a minority faith may not have enough space to provide facilities for all to pray. Moreover, some schools with a religious character do not feel it is in keeping with their ethos to designate prayer facilities for other faiths (Wilson 2015). In such circumstances, pupils sometimes adapt their prayer routines to fit around school hours. For example, Muslim pupils may not strictly adhere to all five of their daily prayers, or may 'catch up' when they return home (Wilson 2015). Hemming (2015) found that pupils may even resort to praying in toilet cubicles due to the lack of provision made for prayer space in schools. Such examples highlight the creative ways that pupils find to negotiate school arrangements and their limitations, thus providing for their own spiritual and cultural needs.

This section has highlighted the contradictory nature of educational policy in relation to religion and belief, and some of the implications of these tensions for religious citizenship. Whilst one strand of policy requires schools to provide for pupils' spiritual, moral, social and cultural development, regardless of background, another demands daily assemblies that privilege Christian worship. These tensions are further exacerbated by spatial and temporal constraints that impede the ability of schools to adequately provide for issues such as minority religious prayer needs. As a result, 
schools are not always able to fully accommodate the religious and non-religious needs of pupils to the satisfaction of all concerned, leading to unequal experiences for different groups. In these circumstances, pupils may be compelled to employ their own creative responses to the problematic situations they are presented with, further highlighting the role of multiple actors in the contestation and negotiation of religious citizenship.

\section{Belonging: Pupil Values and Interfaith Relations}

Another aspect of religious citizenship in education is the extent to which schools create an environment where pupils from different religious and non-religious backgrounds feel a sense of belonging as valued members of the school community and interact harmoniously as a result. The legal and curriculum frameworks in England and Wales are generally supportive of this aim, with the school inspectorates assessing schools on issues such as valuing diversity, promoting respect and tolerance, and preventing bullying and discrimination (Estyn 2017, Ofsted 2017). In England, schools are expected to promote 'Fundamental British Values' including "mutual respect for and tolerance of those with different faiths and beliefs and those without faith" (Ofsted 2017:40). The non-statutory subject of Personal, Social, Health and Economics Education (PSHE) or Personal and Social Education (PSE) as it is known in Wales, also plays a key role, covering topics such as the celebration of difference (e.g. Welsh Assembly Government 2008).

Despite the above policy frameworks, research indicates that children from both religious and non-religious backgrounds often fear being negatively stereotyped or experience bullying in school on the basis of their beliefs (e.g. Moulin 2015). A survey conducted by Weller et al. (2015) found that a majority of survey respondents from almost all religious groups experienced some unfair treatment from other pupils at school because of their religion or worldview. Examples included name-calling, social exclusion and ridiculing beliefs. Some studies have found that pupils from nonreligious backgrounds can be less tolerant of religious perspectives (Mckenna et al. 2009) but others have shown that non-religious pupils can also be subjected to prejudice from both teachers and peers (Madge et al. 2014). Such experiences may 
contribute to informal religious segregation, given that friendship groups in diverse schools are often relatively homogenous (Smith 2005).

One of the ways that schools can combat such experiences is through the values they foster amongst pupils. There are variations in the extent to which schools in England and Wales explicitly recognise diversity of religion and belief, but most appear to encourage a climate of tolerance and respect for difference (e.g. Keddie 2014, Hemming 2015). There is also plenty of evidence in the research literature to suggest that schools with a religious character actively educate pupils to respect religious difference (Ipgrave 2016, Wilson 2015). However, there can be limits to the effectiveness of schools in their promotion of these citizenship values. Despite its 'ethos of tolerance', the school in Welply's (2017) research inadvertently reinforced division between pupils of different religious backgrounds due to a lack of opportunities for pupils to discuss, explore and understand their differences and commonalities.

The above example points to the need for schools to do more than simply promote respectful attitudes and tolerance amongst pupils, instead creating the conditions for positive interfaith encounters and the prevention of bullying. Research shows that many young people view schools as playing an important role in facilitating healthy interfaith relations (Madge et al. 2014) but a significant proportion believe their schools could do more to help different groups get along well together (Conroy et al. 2013). The literature documents a number of approaches to building good interfaith relations in schools, including creating a climate where religious-based bullying is not accepted and encouraging open discussion about different perspectives and common values in RE and PSE/PSHE (Hemming 2015, Jackson 2004).

Schools with a less diverse pupil intake may have a more difficult task in facilitating interfaith encounters. This is true of many schools, but particularly those faith schools with religiously homogenous pupil intakes (Berkley \& Vij 2008). Initiatives that build links between schools with different religious demographics, such as school 'pairing' and joint activities, events and visits, represents one approach to this dilemma (e.g. Breen 2009). Technology can also be harnessed for this purpose, by setting up email, instant messaging, and video conferencing exchanges with other schools (e.g. Ipgrave 2009). If well managed, programmes like these have the potential to facilitate an 
increased understanding of others' perspectives. They may also help to develop a more inclusive type of religious citizenship where pupils from all religious and nonreligious backgrounds feel a sense of belonging to the school and the wider community. Such developments would align well with wider social and public policy agendas in the UK that emphasise the need for stronger interfaith relations and understanding amongst citizens, and that view schools as playing an important role in achieving this (e.g. Casey 2016).

\section{Conclusion}

This chapter has explored the issue of religious citizenship in schools in England and Wales through a focus on faith schools and pupil admissions, RE and festivals, collective worship and prayer, and pupil values and interfaith relations. Collectively these aspects constitute an important dimension of the informal citizenship education that schools provide to pupils on the basis of their religion and belief. By exploring the existing literature on these topics, a number of crosscutting themes have emerged that shed further light on religious citizenship in the context of education. They underline the involvement of multiple actors in the fluid and contested nature of religious citizenship, as well as its constitution through a range of everyday practices and discourses.

The influence of the state on religious citizenship, through educational policies and frameworks, is a central theme. There is a clear tension evident between respecting Britain's religious heritage through the privileging of Christianity, and ensuring fair treatment for minority religious and non-religious groups through a more neutral approach. This is reflected in the over-representation of Christian faith schools and the prioritising of Christianity in RE and collective worship on the one hand, but the requirement to provide for the spiritual and cultural development of all pupils and the role of PSE/PSHE and the inspectorates in valuing diversity of religion and belief on the other. Schools are then left to find an appropriate path through these competing policy requirements.

The role of the school is therefore highly significant for the structuring of religious citizenship. The decisions that faith schools make regarding pupil admissions can 
reinforce or mitigate inequities in access to education. The religious festivals that a school chooses to mark, and the way it chooses to mark them, can have an impact on which groups feel recognised. The arrangements that schools make for pupils' prayer and reflection, and for collective worship, can determine how well Christian, nonreligious and pupils from minority faith backgrounds are included and accommodated. The approach that schools take to promoting cohesive values and facilitating meaningful encounters between different groups can influence the extent to which pupils feel they belong to the school and wider community. School policies and practices therefore have real implications for the educational opportunities and experiences of different religious and non-religious groups.

Schools are not, however, the only agents involved in influencing religious citizenship. Parents from minority groups are active in challenging inequities by making use of church schools for their own ends, lobbying for more diverse representation of religious festivals and non-religious traditions in $\mathrm{RE}$, or pushing for accommodations in collective worship and provision for pupils' cultural and spiritual needs. However, other groups of parents use their resources to try and maintain Christian privilege, by ensuring access to high performing church schools or questioning the celebration of non-Christian festivals and the 'dilution' of Christian worship in assemblies. Pupils also negotiate school arrangements through subtle resistance in RE and collective worship, or creative responses to issues arising with prayer. Pupils can also undermine school attempts to promote respect and tolerance by participating in religious-based bullying. The challenge for schools is to find a way to balance the needs and interests of parents and pupils from these different groups, thus contributing to more inclusive forms of religious citizenship.

\section{Acknowledgements}

Many thanks to Connor Stokes for literature search and review work undertaken in connection with this chapter.

\section{Notes}


1. Education is a devolved matter in the UK, with separate systems operating in England, Wales, Scotland and Northern Ireland. However, the role of religion in schooling in England and Wales has always been quite similar, reflecting the close links between the two education systems prior to Welsh devolution in 1999. England and Wales also share a decennial Census, which is administered separately from the Censuses in Scotland and Northern Ireland, meaning that religious demographic trends in the two nations are typically considered together.

2. In the 2011 Census, the most numerous affiliations in the 'Other Religion' category included Pagan, Spiritualist, Mixed Religion, Jain and Ravidassia.

3. Parents in England and Wales are legally permitted to withdraw their child from school and educate her/him through home schooling instead.

4. Voluntary controlled and foundation faith schools are fully funded by the state, but maintain a distinctive religious ethos and character, with the latter enjoying greater autonomy in relation to school governance. Voluntary aided faith schools are state funded but are expected to raise $10 \%$ of their own capital funding costs. They maintain a distinctive religious ethos and character, and enjoy greater autonomy in relation to school governance, pupil admissions and RE than voluntary controlled faith schools.

5. Academies are independent, state-funded schools, which are run by charitable trusts and sometimes sponsored by other groups (including faith groups). Free schools are independent, state-funded schools, which have been set up by parents, teachers or other organisations (including faith groups) to meet local demand. Both types of school receive their funding directly from central government, rather than a local education authority. Faith-based academies and free schools enjoy similar privileges to voluntary aided faith schools regarding pupil admissions and RE.

\section{References}

Allen, R. and A. West (2009) Religious schools in London: school admissions, religious composition and selectivity. Oxford Review of Education 35(4) pp. 471-494

Allen, R. \& West, A. (2011) Why do faith secondary schools have advantaged intakes? The relative importance of neighbourhood characteristics, social background and religious identification amongst parents. British Educational Research Journal 37(4) pp. 691-712

Baumann, G. (1996). Contesting culture: discourses of identity in multi-ethnic London. Cambridge: Cambridge University Press.

Baumfield, V. (2003) 'The dignity of difference: faith and schooling in a liberal democracy', British Journal of Religious Education', 25(2): 86-88.

Bell, D. (1995) 'Pleasure and danger: the paradoxical spaces of sexual citizenship', Political Geography, 14(2): 139-153.

Berkley, R. and Vij, S. (2008) Right to Divide? Faith Schools and Community Cohesion, London: Runnymede Trust.

Bouma, G.D. and Ling, R. (2009) 'Religious diversity', in P.B. Clarke (ed.) The Oxford Handbook of the Sociology of Religion, Oxford: Oxford University Press, pp.507-524.

Breen, D. (2009) 'Religious diversity, inter-ethnic relations and the Catholic school: introducing the responsive approach to single faith schooling', British Journal of Religious Education, 31(2), pp. 103-115. 
Butler, T. and C. Hamnett (2012) Praying for success? Faith schools and school choice in East London. Geoforum 23(6) pp. 1242-1253.

Casey, D.L. (2016) The Casey Review: A Review into Opportunity and Integration, London: Department of Communities and Local Government. Available at: https://assets.publishing.service.gov.uk/government/uploads/system/uploads/attachment data/fil e/575973/The Casey Review Report.pdf (Accessed 28 June 2018).

Catholic Education Service (2008) Catholic Schools, Children of Other Faiths and Community Cohesion: Cherishing Education for Human Growth, London: CES. Available at: https://www.catholiceducation.org.uk/guidance-forschools/equality/item/download/7209 42c9fc43f229d55978aa08008579d616 (Accessed 1 March 2018).

Chouinard, V. (2004) 'Making feminist sense of the state and citizenship', in L.A. Staeheli, E. Kofman and L. Peake (eds) Mapping Women, Making Politics: Feminist Perspectives on Political Geography, Abingdon: Routledge, pp.227-244.

Copley, T. (1997) Teaching Religion; Fifty Years of Religious Education in England and Wales, Exeter: University of Exeter Press.

Copley, T. (2000) Spiritual Development in the State School: A Perspective on Worship and Spirituality in the Education System of England and Wales, Exeter: University of Exeter Press.

Conroy, J.C., Lundie, D., Davis, R.A., Baumfield, V., Barnes, P.L., Gallagher, T., Lowden, K., Bourque, N. and Wenell, K.J. (2013) Does Religious Education Work? A Multi-dimensional Investigation, London: Bloomsbury.

Coughlin, S. (2016) 'Muslim families sending children to Catholic schools', BBC News 01/12/16 [ONLINE] Available at: http://www.bbc.co.uk/news/education-38157812 (accessed 14 February 2018).

Estyn (2017) Guidance Handbook for the Inspection of Primary Schools, Cardiff: Estyn. Available at: https://www.estyn.gov.wales/sites/default/files/documents/Guidance\%20handbook\%20for\%20the \%20inspection\%20of\%20primary\%20schools\%20-\%202017.pdf (Accessed 28 February 2018).

Fancourt, N. (2017) 'Teaching about Christianity: a configurative review of research in English Schools', Journal of Beliefs and Values, 38(1), pp. 121-133.

Fair Admissions Campaign (2013) 'How admissions arrangements work at different kinds of school' [ONLINE] Available at: http://fairadmissions.org.uk/why-is-this-an-issue/the-law-on-admissions/ (Accessed 15 March 2018).

Flint, J., (2007) Faith schools, multiculturalism and community cohesion: Muslim and Roman Catholic state schools in England and Scotland. Policy and Politics 35 (2), 251-268.

Francis, L.J. and Robbins, M. (2011) 'Teaching secondary RE at faith schools in England and Wales: listening to the teachers', Journals of Beliefs and Values, 32(2), pp. 219-233.

Gill, J. (2000a) 'The contribution of the act of collective worship to spiritual and moral development'. In Best, R. (Ed.), Education for spiritual, moral, social and cultural development. London: Continuum. pp 106-116.

Gill, J. (2000b). 'Approaches to collective worship in multifaith schools'. In Leicester, M., Modgil, C,. and Modgil, S. (Eds.), Spiritual and religious education. London: Falmer. pp. 209-219.

Hemming, P.J. (2015) Religion in the Primary School: Ethos, Diversity and Citizenship. Oxon: Routledge.

Hemming, P.J. (2018a) 'Faith schools, community engagement and social cohesion: a rural perspective', Sociologia Ruralis. Available from: https://doi.org/10.1111/soru.12210

Hemming, P.J. (2018b) 'No Offence to God but I Don't Believe in Him': Religion, Schooling and Children's Rights', Ethnography and Education, 13(2): pp.154-171.

Hemming, P.J. \& Roberts, C. (2018) 'Church schools, educational markets and the rural idyll', British Journal of Sociology of Education, 39(4): 501-517.

Ho, E. (2006) 'Negotiating belonging and perceptions of citizenship in a transnational world: Singapore, a cosmopolis?', Social and Cultural Geography, 7(3): 385-401.

Ipgrave, J. (1999) 'Issues in the delivery of religious education to Muslim pupils: Perspectives from the classroom', British Journal of Religious Education, 21(2), pp. 80-89.

Ipgrave, J. (2009) 'The language of friendship and identity: Children's communication choices in an interfaith exchange', British Journal of Religious Education, 31(3), pp. 213-225.

Ipgrave, J. (2016) 'Identity and inter religious understanding in Jewish schools in England', British Journal of Religious Education, 38(1): 47-63.

Jackson, R. (2001) 'Faith-based schools and religious education within the state system in England and Wales', British Journal of Religious Education, 21(2): 80-89. 
Jackson, R. (2004) Rethinking religious education and plurality: Issues in diversity and pedagogy. Psychology Press.

Jackson, R. (2012) (ed.) Religion, Education, Dialogue and Conflict: Perspectives on Religious Education Research, London: Routledge.

Joppke, C. (2007) 'Transformation of citizenship: status, rights, identity', Citizenship Studies, 11(1): $37-48$.

Kay, W. and Francis, L. (2001) 'Religious Education and School Assembly in England and Wales: what do religious minorities think?', in Heimbrock, H. G., Scheilke, C. T. and Schreiner, P. (eds.) Towards Religious Competence: Diversity as a Challenge for the Education in Europe, Munster: LIT, pp. 117-128.

Keddie, A. (2014) 'Students' understanding of religious identities and relations: issues of social cohesion and citizenship', Education, Citizenship and Social Justice, 9(1), pp. 81-93.

Kymlicka, W. (2007) Multicultural Odysseys: Navigating the New International Politics of Diversity, Oxford: Oxford University Press.

Long, R. and Bolton, P. (2017) Faith Schools in England: FAQs (House of Commons Briefing Paper 06972), London: House of Commons Library. Available at: http://researchbriefings.files.parliament.uk/documents/SN06972/SN06972.pdf (Accessed 1 March 2018)

Louden, L., 2012. Distinctive and Inclusive: The National Society and Church of England Schools 1811-2011. The National Society, London.

Madge, N., Hemming, P. and Stenson, K. (2014) Youth on Religion: The development, negotiation, and impact of faith and non-faith identity, London: Routledge.

Machacek, D.W. (2003) 'The problem of pluralism', Sociology of Religion, 64(2): 145-161.

Marshall, T.H. (1950[1973]) Class, Citizenship and Social Development, Westport, CT: Greenwood.

McKenna, U., Neill, S., Jackson, R. (2009) Personal worldviews, dialogue and tolerance: students' views on religious education in England, in: Valk, P., Bertram-Troost, G., Friederici, M. and Beraud, C. (Eds.) Teenagers' Perspectives on the Role of Religion in their Lives, Schools and Societies. A European Quantitative Study, Religious Diversity and Education in Europe Series. Münster: Waxmann, pp. 49-70.

Mogra, I. (2017)' Learning through observations: the potential of collective worship in primary schools', Pastoral Care in Education, 35(1), pp. 3-12.

Moulin, D. (2011) 'Giving voice to 'the silent minority': the experience of religious students in secondary school religious education lessons', British Journal of Religious Education, 33(3), pp. 313-326.

Moulin, D. (2015) 'Religious identity choices in English secondary schools', British Educational Research Journal, 41(3), pp. 489-504.

National Association of Teachers of Religious Education (2017) 'Legal requirements: RE - Statutory requirements and curriculum information'. [ONLINE] Available at: https://www.natre.org.uk/aboutre/legal-requirements/ (Accessed 9 February 2018).

Nesbitt, E. (2004) Intercultural Education: Ethnographic and Religious Approaches, Brighton: Sussex Academic Press.

Office for National Statistics (2015) 'How religion has changed in England and Wales'. [ONLINE] Available at: http://visual.ons.gov.uk/2011-census-religion/ (Accessed 28 February 2018)

Ofsted (2017) School Inspection Handbook: Handbook for Inspecting Schools in England under Section 5 of the Education Act 2005. Manchester: Ofsted. Available at: https://www.gov.uk/government/uploads/system/uploads/attachment data/file/678967/School in spection handbook section 5.pdf (Accessed 28 February 2018).

Painter, J. and Philo, C. (1995) 'Spaces of citizenship: an introduction', Political Geography, 14(2): 107-120.

Power, S. and Taylor, C. (2013) 'Social justice and education in the public and private spheres', Oxford Review of Education, 39(4): 464-479.

Pring, R. (2018) The Future of Publicly Funded Faith Schools: A Critical Perspective, Oxon: Routledge.

R (Fox) v Secretary of State for Education [2015] EWHC 3403.

Revell, L. (2007) 'Student Primary teacher and their experience of religious education in schools', British Journal of Religious Education, 27(3), pp. 215-226.

Richardson, N., Niens, U., Mawhinney, A. and Chiba, Y. (2013) 'Opting out or opting in? Conscience clauses, minority belief communities and the possibility of inclusive religious education in Northern Ireland', British Journal of Religious Education, 35(3), pp. 236-250. 
Scourfield, J.B., Gilliat-Ray, S., Khan, A. and Sameh, O. (2013) Muslim Childhood: Religious Nurture in a European Context, Oxford: Oxford University Press.

Smith, G. (2005) Children's Perspectives on Believing and Belonging, London: National Children's Bureau for the Joseph Rowntree Foundation.

Smith, G. and Smith, S. (2013) 'From values to virtues: An investigation into the ethical content of English primary school assemblies', British Journal of Religious Education, 35(1), pp. 5-19.

Staeheli, L.A., Ehrkamp, P., Leitner, H. and Nagel, C.R. (2012) 'Dreaming the ordinary: daily life and the complex geographies of citizenship', Progress in Human Geography, 36(5): 628-644.

Watson, J. (2010) 'Including secular philosophies such as humanism in locally agreed syllabuses for religious education', British Journal of Religious Education ,32(1), pp. 5-18.

Weller, P., Purdam, K., Ghanea, N. and Cheruvallil-Contractor, S. (2015) Religion or Belief, Discrimination and Equality: Britain in Global Contexts, London: Bloomsbury. pp. 83-120.

Welply, O. (2017) 'I'm not being offensive but...': intersecting discourses of discrimination towards Muslim children in school', Race Ethnicity and Education, 21(3), pp.370-389.

Welsh Assembly Government (2008) Personal and Social Education Framework for 7 to 19-YearOlds in Wales, Cardiff: WAG. Available at:

http://learning.gov.wales/docs/learningwales/publications/130425-personal-and-social-educationframework-en.pdf (Accessed 28 February 2018).

Welsh Government (2018) 'Address list of schools.' [ONLINE] Available at: https://gov.wales/statisticsand-research/address-list-of-schools/?lang=en (Accessed 12 May 2018).

Wilson, T. (2015) Hospitality and Translation: An Exploration of How Muslim Pupils Translate their Faith in the Context of an Anglican Primary School. Cambridge Scholars Publishing. 